\title{
MUSCULAR ANATOMY OF THE PECTORAL GIRDLE AND FORELIMB OF Iguana i. iguana (Squamata: Iguanidae)
}

\author{
ANATOMIA MUSCULAR DO CÍNGULO PEITORAL E MEMBRO TORÁCICO DE \\ Iguana i. iguana (Squamata: Iguanidae)
}

\section{Letícia Menezes FREITAS ${ }^{1}$; Dayane Kelly Sabec PEREIRA ${ }^{2}$; Kleber Fernando PEREIRA ${ }^{3}$; Odeony Paulo dos SANTOS ${ }^{1}$; Fabiano Campos LIMA ${ }^{3}$}

1. Graduation Student. Human and Comparative Anatomy Laboratory, Federal University of Goiás, Jataí, Brazil; 2. PhD Student. Human and Comparative Anatomy Laboratory, Federal University of Goiás, Jataí, Brazil; 3. Professor, PhD. Human and Comparative Anatomy Laboratory, Federal University of Goiás, Jataí, Brazil. fabianocl21 @ hotmail.com

\begin{abstract}
Green iguana has arboreal and terrestrial habits. It is widely distributed in Central and South America, inhabiting several biomes in Brazil. Some researches were focused on this species, however, morphological information are still limited. With that in sight, we aimed to add data to the anatomical knowledge. Two post mortem specimen of Iguana i. iguana were acquired, donated by a scientific breeding, and dissected. To describe the muscles we refuted the skin and removed the fascias, individualizing the muscles. We identified the following muscles: pectoralis, deltoideus clavicularis, deltoideus scapularis, trapezius, latissimus dorsi, coracobrachialis brevis, coracobrachialis longus, serratus thoracis, levator scapulae, biceps brachii and triceps brachii. Some of them, like coracobrachialis brevis, present conservative anatomy, originating from the ventral surface of the coracoid and inserting onto the proximal humerus. Some, like trapezius and biceps brachii, are similar to other reptile species, trapezius takes its origin from the thoracodorsal fascia and biceps arises by two heads and inserts on the radial tuberosity. Deltoideus clavicularis and deltoideus scapularis share a common insertion tendon. Pectoralis varies its origin and divisions, however, the insertion always occur on the deltopectoral crest. Triceps brachii is comprised of four heads. Its long medial head originates via a tendinous arc, feature described only in crocodilians. We conclude that Iguana i. iguana forelimb musculature is similar to other reptiles, presenting its own characteristics that reflect its habits.
\end{abstract}

KEYWORDS: Musculature. Green iguana. Reptiles.

\section{INTRODUCTION}

Iguanidae comprises several genera, among them Iguana (BLAIR, 1995; COSTA; BÉRNILS, 2015). Popularly known as green iguana, Iguana iguana iguana is widely distributed in Central and South America, occurring from northern Mexico to south-eastern Paraguay and Brazil, in which it occurs in the Amazonia, Caatinga, and Pantanal (BARTEN, 2003; BLAIR, 1995; DESBIEZ; CAMPOS, 2013; SWANSON, 2004).

Green iguanas are arboreal, but spends a considerably amount of time on the ground and in the water. In favourable weather, they stay in trees for several days, using the water to scape predators and bushes and holes to hide. They choose its tree based on the proximity to a watercourse and food availability, being herbivorous, they feed off sprouts, leaves, fruits and flowers (BLAIR, 1995; BARTEN, 2003; SWANSON, 2004).

The musculature, in collaboration with the skeleton and the articulations, helps to sustain the body. Among several functions of the muscles, such as bowl movements, transport of blood in the vessels, and vocalization, it also provides strength to movements performed by animals, defining speed and restraining muscle displacement. The body of the amphibians and most reptiles, such as lizards, are maintained close to the ground due to the lateral positioning of the limbs. Animals that climb benefit on short limbs and a sprawling gait, to keep the body as close to the surface underneath as possible. In an evolutionary scale, limbs have become more important sustaining movements in tetrapods, because its most important function is to move the body as efficiently as possible, and it is necessary a powerful musculature to lift the limbs and keep the body off the ground (BRINKMAN, 1981; KARDONG, 2014; LIEM et al., 2012; MORO; ABDALA, 2006; ZAAF et al. 1999).

In each step a lizard takes its body bends from side to side, and because of that its locomotion pattern is completely different than the standardized quadruped mammalian (AVERY et al. 1987; FARLEY, 1997; RITTER, 1992; RUSSEL; BAUER, 2008). According to Avery et al. (1987), lizards usually move alternating short periods of locomotion with pauses or they can be completely sprawled for basking. In nature, due to the lizards reduced size, they may inhabit a diversified environment, specialization of its locomotor system is necessary to overpass the obstacles on their path 
and this requires an adapted limbs musculature, to walk, climb and run.

The appendicular musculature is more conspicuous and the axial musculature is reduced and tends to differentiate in specialized muscles (KARDONG, 2014; LIEM et al., 2012; MORO; ABDALA, 2006). Generally, in tetrapods, the limbs present ventral and dorsal musculature compartments, that perform flexion and extension, respectively (MEERS, 2003), however elevation and depression are also important actions (HAINES, 1939). Although some related muscles, such as levator scapulae, serratus and trapezius, are not part of the musculature of the limb (ROMER, 1944), they are directly related to its functions. Comparative anatomy provides data to create hypothesis to the similarities and differences found among distinct taxa and its implications.

Although the hypaxial and pelvic outlet muscles of Iguana i. iguana have been described, it lacks in the literature the morphology of the pectoral girdle and forelimb musculature of this species (Akita, 1992; Carrier, 1990). With this in mind, we aimed to describe these muscles to add data to the morphological knowledge. The anatomical description of the musculature of Iguana i. iguana can also provide information that may be useful in clinical treatments of this species, often adopted as a pet (BLAIR, 1995).

\section{MATERIALS AND METHODS}

We acquired two adult females specimen of Iguana i. iguana (Linnaeus, 1758), post mortem, from a scientific breeding in UNESP - Rio Claro, which criteria are supported by Normative Instruction $\mathrm{n}^{\mathrm{o}} 154 / 2007$ - IBAMA and current legislation $\left(\mathrm{n}^{\mathrm{o}} 11.794 / 2008\right.$ that regulates animal research in Brazil) and approved by the ethics committee (UNESP-CEUA 4173/2009 and UFUCEUA 070/2012). The frozen animals were sent to the Human and Comparative Anatomy Laboratory from the Federal University of Goiás - Jataí.

We used the usual dissection procedures, making a longitudinal incision along the midline and refuting the skin to expose the musculature. They were fixed and preserved in formaldehyde $10 \%$. Posteriorly, we individualized the regions of interest and then identified the muscles, according with its features, such as sites of origins and insertions. Then we photographed and documented the musculature using the camera Cannon $\alpha 200$.

We described the ventral and dorsal musculature of the pectoral girdle and forelimb of Iguana $i$. iguana through comparison with the literature of other reptiles. The nomenclature we used to identify and describe the muscles was based on Moro and Abdala $(2004 ; 2006)$ and Jenkins and Goslow (1983) about lizards, and Meers (2003) about crocodilians.

\section{RESULTS}

The anatomical description of the observed muscles of the pectoral girdle, estilopodium and zeugopodium of the forelimb follows in the tables 1 , 2 and 3 and can be observed in figures 1 and 2 .

Table 1. Dorsal and ventral muscles of the pectoral girdle and shoulder of Iguana iguana iguana.

\begin{tabular}{|c|c|c|c|}
\hline Muscle & Origin & Insertion & Features \\
\hline Pectoralis & $\begin{array}{l}\text { Cranial margin of the VI rib, } \\
\text { sternum and episternum, along the } \\
\text { midline. }\end{array}$ & $\begin{array}{c}\text { Apex of the deltopectoral } \\
\text { crest }\end{array}$ & $\begin{array}{l}\text { Large, flat, fan-shaped, } \\
\text { segmented in three parts, } \\
\text { ascendant, descendent, and } \\
\text { transverse. }\end{array}$ \\
\hline $\begin{array}{l}\text { Deltoideus } \\
\text { clavicularis }\end{array}$ & Middle portion of interclavicle & $\begin{array}{l}\text { Through a common tendon } \\
\text { with deltoideus scapularis } \\
\text { inserted onto the } \\
\text { dorsocaudal surface of the } \\
\text { deltopectoral crest }\end{array}$ & $\begin{array}{l}\text { Thin and elongated on the } \\
\text { medioventral surface of the } \\
\text { pectoral girdle }\end{array}$ \\
\hline $\begin{array}{l}\text { Deltoideus } \\
\text { scapularis }\end{array}$ & $\begin{array}{l}\text { Broadly on the lateral surface of the } \\
\text { scapula }\end{array}$ & $\begin{array}{l}\text { Through a common tendon } \\
\text { with deltoideus clavicularis } \\
\text { inserted onto the } \\
\text { dorsocaudal surface of the } \\
\text { deltopectoral crest }\end{array}$ & $\begin{array}{l}\text { Overlaid cranially by the } \\
\text { caudal projection of the } \\
\text { trapezius }\end{array}$ \\
\hline Trapezius & $\begin{array}{l}\text { Thoracodorsal fascia, along the } \\
\text { spinous processes of the vertebrae, } \\
\text { in the midline }\end{array}$ & $\begin{array}{l}\text { Intermingle fibers with the } \\
\text { dorsal margin of deltoideus } \\
\text { scapularis and inserts onto } \\
\text { the cranial margin of the } \\
\text { scapula }\end{array}$ & $\begin{array}{c}\text { Overlay deltoideus } \\
\text { scapularis dorsally, through } \\
\text { a caudal projection of fibers. }\end{array}$ \\
\hline
\end{tabular}




\begin{tabular}{|c|c|c|c|}
\hline Latissimus dorsi & $\begin{array}{l}\text { Thoracodorsal fascia, along the } \\
\text { spinous processes of the vertebrae, } \\
\text { in the midline, and ventrocaudally } \\
\text { on the dorsal margin of the ribs I-V }\end{array}$ & $\begin{array}{l}\text { Caudal surface of the } \\
\text { proximal humerus }\end{array}$ & $\begin{array}{c}\text { Flat and large, shows } \\
\text { oblique fibers forwarded } \\
\text { cranially }\end{array}$ \\
\hline $\begin{array}{l}\text { Coracobrachialis } \\
\text { brevis }\end{array}$ & $\begin{array}{l}\text { Cranial margin and ventral surface } \\
\text { of the coracoid }\end{array}$ & $\begin{array}{l}\text { Large and stout tendon on } \\
\text { the cranial edge of the } \\
\text { deltopectoral crest, on the } \\
\text { medial face of the proximal } \\
\text { humerus }\end{array}$ & $\begin{array}{l}\text { Triangular-shaped, located } \\
\text { below deltoideus clavicularis } \\
\text { on the lateral margin of the } \\
\text { pectoralis }\end{array}$ \\
\hline $\begin{array}{l}\text { Coracobrachialis } \\
\text { longus }\end{array}$ & Coracoid & Middle third of the humerus & $\begin{array}{c}\text { Overlaid by coracobrachialis } \\
\text { brevis and biceps brachii. } \\
\text { Presents an area of circular } \\
\text { cross section }\end{array}$ \\
\hline Serratus thoracis & Cranial margin of the ribs I and II & $\begin{array}{l}\text { Caudal margin of the } \\
\text { scapula }\end{array}$ & $\begin{array}{l}\text { Thin and quadrangular, } \\
\text { overlaid by latissimus dorsi }\end{array}$ \\
\hline Levator scapulae & $\begin{array}{l}\text { Lateral surface of the neck, attached } \\
\text { to the cervical ribs and processes } \\
\text { of the vertebrae }\end{array}$ & $\begin{array}{l}\text { Along the cranial margin of } \\
\text { the scapula }\end{array}$ & $\begin{array}{l}\text { Completely overlaid by } \\
\text { trapezius. Broad and thin, } \\
\text { elongated on the lateral } \\
\text { surface of the pectoral girdle }\end{array}$ \\
\hline
\end{tabular}

Table 2. Forelimb muscles of the estilopodium of Iguana iguana iguana.

\begin{tabular}{|c|c|c|c|}
\hline Muscle & Origin & Insertion & Features \\
\hline Biceps brachii & $\begin{array}{l}\text { Presents two origins, the distal head } \\
\text { originates from the ventral surface of } \\
\text { the coracoid, under the descendent } \\
\text { part of the pectoralis, the proximal } \\
\text { head takes its origin from the caudal } \\
\text { surface of the deltopectoral crest, on } \\
\text { the proximal humerus, lateral to the } \\
\text { tendon of the first head. }\end{array}$ & Radial tuberosity & $\begin{array}{l}\text { The flat, thin tendon of the } \\
\text { distal head runs over the surface } \\
\text { of the coracobrachialis brevis } \\
\text { The fusiform proximal head is } \\
\text { laterally located on the cranial } \\
\text { surface of the limb, has parallel } \\
\text { fibers and stout tendon. }\end{array}$ \\
\hline $\begin{array}{l}\text { Triceps longus } \\
\text { lateralis }\end{array}$ & Dorsal on the deltopectoral crest & Olecranon & $\begin{array}{l}\text { Fusiform fibers runs through the } \\
\text { lateral surface of the humerus }\end{array}$ \\
\hline $\begin{array}{l}\text { Triceps longus } \\
\text { caudalis }\end{array}$ & $\begin{array}{l}\text { Takes its origin via a tendinous arc } \\
\text { on the lateral surface of the shoulder, } \\
\text { between the scapula and the dorsal } \\
\text { surface of the deltopectoral crest }\end{array}$ & Olecranon & $\begin{array}{l}\text { The tendinous arc overlays the } \\
\text { coracobrachialis brevis laterally. } \\
\text { This thin tendon presents a } \\
\text { broad end on the bone surface }\end{array}$ \\
\hline $\begin{array}{l}\text { Triceps brevis } \\
\text { intermedius }\end{array}$ & $\begin{array}{c}\text { Medial surface of the proximal } \\
\text { humerus. }\end{array}$ & Olecranon & $\begin{array}{l}\text { Presents another tendon arising } \\
\text { medially on the sternum. }\end{array}$ \\
\hline $\begin{array}{l}\text { Triceps brevis } \\
\text { caudalis }\end{array}$ & Craniodorsal surface of the humerus & Olecranon & Long and narrow \\
\hline
\end{tabular}

Table 3. Forelimb muscles of the zeugopodium of Iguana iguana iguana.

\begin{tabular}{|c|c|c|c|}
\hline Muscle & Origin & Insertion & Features \\
\hline $\begin{array}{c}\text { Extensor carpi } \\
\text { ulnaris }\end{array}$ & $\begin{array}{l}\text { Cranial epicondyle of the } \\
\text { humerus }\end{array}$ & Shaft of the ulna & $\begin{array}{l}\text { Large, broad, positioned medially } \\
\text { on the zeugopodium. }\end{array}$ \\
\hline $\begin{array}{l}\text { Extensor digitorum } \\
\text { longus }\end{array}$ & $\begin{array}{l}\text { Cranial epicondyle of the } \\
\text { humerus }\end{array}$ & $\begin{array}{l}\text { Thin tendon attached in } \\
\text { distal phalanges of the } \\
\text { digits I, II and III }\end{array}$ & $\begin{array}{l}\text { Fusiform and presents parallel } \\
\text { fibers on the intermediate region of } \\
\text { the zeugopodium. The broad tendon } \\
\text { on the dorsal surface of the hand } \\
\text { divides into three long and thin } \\
\text { insertion tendons. }\end{array}$ \\
\hline $\begin{array}{l}\text { Extensor carpi } \\
\text { radialis }\end{array}$ & $\begin{array}{l}\text { Cranial epicondyle of the } \\
\text { humerus }\end{array}$ & $\begin{array}{l}\text { Distal half of the radius } \\
\text { and radial carpal bone }\end{array}$ & $\begin{array}{c}\text { It has a large cross sectional origin, } \\
\text { and a reduced belly in a distal } \\
\text { portion. Wide tendon laterally on } \\
\text { the wrist }\end{array}$ \\
\hline Pronator teres & $\begin{array}{l}\text { Caudal epicondyle of the } \\
\text { humerus }\end{array}$ & $\begin{array}{l}\text { Along the caudal } \\
\text { margin of the humerus } \\
\text { and on the distal } \\
\text { extremity of the radius }\end{array}$ & $\begin{array}{l}\text { Thick and thin, broad on the } \\
\text { insertion. }\end{array}$ \\
\hline
\end{tabular}




\begin{tabular}{cccc}
\hline $\begin{array}{c}\text { Flexor digitorum } \\
\text { longus }\end{array}$ & $\begin{array}{c}\text { Caudal epicondyle of the } \\
\text { humerus and lateral margin of } \\
\text { the ulna }\end{array}$ & $\begin{array}{c}\text { Five thin and enlogated } \\
\text { tendons along the } \\
\text { palmar surface of the } \\
\text { digits I-V, inserted on } \\
\text { the base of the distal } \\
\text { phalange }\end{array}$ & $\begin{array}{c}\text { Two distinct origins, humeral and } \\
\text { ulnar, converge in a broad insertion } \\
\text { tendon that divides on the palmar } \\
\text { face on } 5 \text { long and thin tendon to } \\
\text { the digits I-V. }\end{array}$ \\
\hline Pronator profundus & $\begin{array}{c}\text { Broadly on the lateral margin of } \\
\text { the ulna }\end{array}$ & $\begin{array}{c}\text { Distal part of the } \\
\text { medial face of the } \\
\text { radius }\end{array}$ & $\begin{array}{c}\text { Deep, broad and large, oblique } \\
\text { fibers between the zeugopodium } \\
\text { bones. }\end{array}$ \\
\hline
\end{tabular}

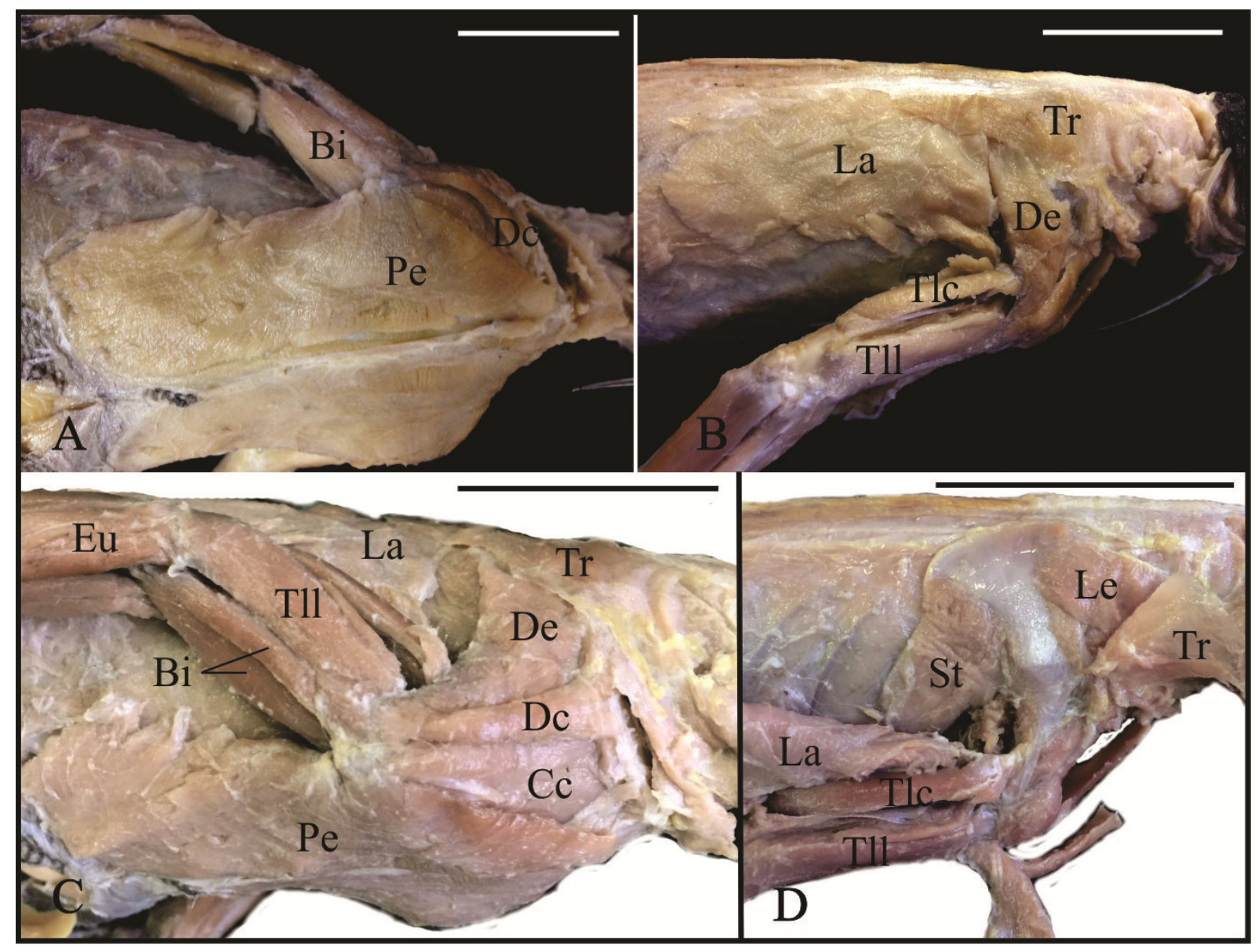

Figure 1. Pictures of Iguana iguana iguana. Ventral view of the pectoral region (A), lateral view of the cranial portion (B), ventrolateral view of the pectoral girdle in superficial (C) and deep aspect (D). Abbreviations: Bi, biceps brachii; Cc, coracobrachialis brevis; Dc, deltoideus clavicularis; De, deltoideus scapularis; Eu, extensor carpi ulnaris; La, latissimus dorsi; Le, levator scapulae; Pe, pectoralis; St; serratus thoracis; Tlc, triceps longus caudalis; Tll, triceps longus lateralis; Tr, trapezius. Escale $4 \mathrm{~cm}$. 


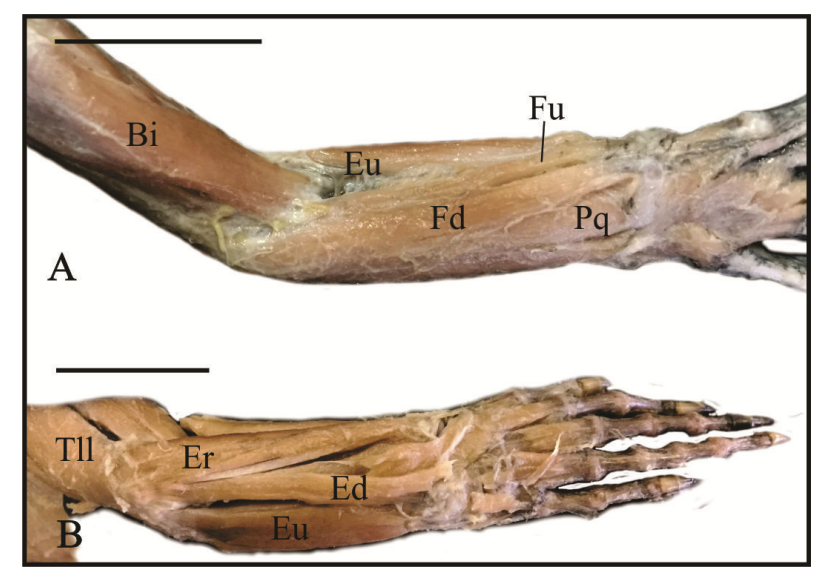

Figure 2. Pictures of the forelimb of Iguana iguana iguana in ventral (A) and dorsal view (B). Abbreviations: $\mathrm{Bi}$, biceps brachii; Ed, extensor digitorum longus; Er extensor carpi radialis; Eu, extensor carpi ulnaris; Fd, flexor digitorum longus; Fu, flexor carpi ulnaris; Pp, pronator profundus; Tll, triceps longus lateralis. Escale $2 \mathrm{~cm}$.

\section{DISCUSSION}

According to Romer (1944) and Kardong (2002), the plesiomorphic condition in reptiles is the existence of a single pectoralis, as in lepdosauria and testudines (ABDALA; DIOGO, 2010; WALKER, 1973). However, crocodilians present two or three heads - cranial and caudal; cranial, caudal and deep (ABDALA; DIOGO, 2010; LIMA et al., 2016; MEERS, 2003). Varanus exanthematicus also presents three heads - anterior, middle e posterior - (JENKINS; GOSLOW, 1983) and we observed the same segmentation in Iguana $i$. iguana, parts ascendant, transverse and descendent.

Muscle pectoralis performs retraction and adduction of the humerus (MEERS, 2003; ROMÃO et al., 2013). It presents fan-shaped morphology, running from the sternum, clavicle and adjacent structures, such as ribs and interclavicle, to the proximal humerus, usually onto the deltopectoral crest - Eublepharis macularius, Gekko gecko, Lacerta agilis exigua, V. exanthematicus, Alligator mississippiensis, Crocodylus siamensis, Crocodylus acutus, Osteolaemus tetraspis, Gavialis gangeticus, Caiman crocodilus crocodilus, Caiman latirostris and Iguana i. iguana (ABDALA; DIOGO, 2010; JENKINS; GOSLOW, 1983; LIMA et al., 2016; MEERS, 2003; ROMÃO et al., 2013; ROMER, 1944; ZAAF et al. 1999).

Classically, muscle deltoideus clavicularis is reported as superficial, occupying a large portion of the scapular surface, it acts as a humerus protactor and supports the shoulder joint (LIMA et al., 2016; MEERS, 2003). Romão et al., (2013), by particular reasons, describes this muscle as $\mathrm{m}$. deltoideus scapularis proximalis in C. latirostris and Zaaf et al. (1999) characterize it as m. clavodeltoideus. In crocodilians, it arises along the cranial margin of the scapula (LIMA et al., 2016; MEERS, 2003; ROMÃO et al., 2013). In L. agilis exigua, the origin occurs from the internal and external surface of the cranial margin of the clavicle (ROMER, 1944). Jenkins and Goslow (1983), distinguished two heads in $V$. exanthematicus, originating from the dorsal surface of the interclavicle and dorsal surface of clavicle and interclavicle, both at the junction of the medial and transverse processes of the vertebrae. However Zaaf et al. (1999) described only one head arising from the interconnection between the clavicle and interclavicle in E. macularius e $G$. gecko.

In the lizard species L. agilis exigua, $V$. exanthematicus, and Iguana i. iguana, m. deltoideus clavicularis fibers converge onto a common insertion tendon with $\mathrm{m}$. deltoideus scapularis (JENKINS; GOSLOW, 1983; ROMER, 1944). It usually inserts onto the deltopectoral crest or adjacent to it (JENKINS; GOSLOW, 1983; LIMA et al., 2016; MEERS, 2003; ROMÃO et al., 2013; ROMER, 1944; ZAAF et al. 1999). In the lizards above mentioned, the common insertion of the $\mathrm{mm}$. deltoideus allows a mechanical advantage to resistance of this muscle that acts on the forelimb stabilization, improving the climbing habit of these species, besides other muscles that contributes to this function.

Lizards mostly have small size, so it is expected no additional belly to be found in $\mathrm{mm}$. deltoideus. Meers (2003) reported a distal slip of the muscle in A. mississippiensis, inserting on the intermuscular septum between $\mathrm{mm}$. humeroradialis and biceps brachii in crocodilians. This is plausible taking into consideration that it sustains great part of the body weight. It also has to be taken into account 
that theses reptiles have distinct phylogenetic relations.

Muscle deltoideus scapularis acts as an important stabilizer of the shoulder joint (MEERS, 2003), it frequently takes its origin from the lateral surface of the scapula, as we observed in Iguana $i$. iguana, presenting some variations. Romão et al., (2013) describes it as deltoideus scapularis distalis in C. latirostris and Zaaf et al. (1999) characterize it as m. scapulodeltoideus. In $V$. exanthematicus, $E$. macularius e G. gecko (JENKINS; GOSLOW, 1983; ZAAF et al. 1999), the origin extends from the scapula to the suprascapula and the clavicle, in L. agilis exigua, it occurs on the external surface of the scapula (ROMER, 1944). In A. mississippiensis, $C$. siamensis, $C$. acutus, $O$. tetraspis and $G$. gangeticus, its origin extends to the adjacent suprascapular cartilage and it inserts on the caudolateral edge of the humeral head (MEERS, 2003). However, in $C$. crocodilus crocodilus e $C$. latirostris, it originates on the craniodistal margin of the scapula, inserting distal to the deltopectoral crest, proximal to the insertion of $\mathrm{m}$. deltoideus clavicularis (JENKINS; GOSLOW, 1983; LIMA et al., 2016; ROMÃO et al., 2013; ROMER, 1944).

Muscle trapezius is superficial, fan-shaped, large and thin, it performs rotation and protaction of the scapula, assisting in locomotor movements (JENKINS; GOSLOW, 1983; LIMA et al., 2016; MEERS, 2003; ROMÃO et al., 2013). It presents two origins in the lizard $V$. exanthematicus, the cranial belly takes its origin from the cranial processes and supraspinal ligament between $\mathrm{C} 3$ and T3 and its also attached to a nuchal fascia, inserting along the cranial margin of the suprascapular cartilage and the dorsal part of the clavicle. The caudal part arises from a distinct aponeurosis and inserts into the cranial half of the lateral aspect of the suprascapular cartilage. All these features are quite different from what we observed Iguana $i$. iguana (JENKINS; GOSLOW, 1983).

We observed in Iguana i. iguana the same features of $\mathrm{m}$. trapezius as in crocodilians, taking its origin from the thoracodorsal fascia and inserting on the cranial margin of the scapula (LIMA et al., 2016; MEERS, 2003; ROMÃO et al., 2013). In $C$. acutus the origin may extend dorsally to the suprascapular cartilage. Some variations in $A$. mississippiensis extends the insertion to the lateral margin of the scapula, passing over $\mathrm{m}$. deltoideus scapularis, with intermingling of some fibers, also present in Iguana i. iguana. This may happen to improve the strength of the contraction of the muscle to aid the maintenance of the shoulder stability. Protaction of the scapular increases the locomotor efficiency in stride movements (MEERS, 2003). Although we have not examined the locomotion pattern of Iguana i. iguana, we can infer based on personal observations that this muscle acts very similar to Peterson (1984) described to chameleons.

Dorsally, muscle latissimus dorsi is continuous to $\mathrm{m}$. trapezius and acts as a strong extensor of the humerus (MEERS, 2003). Romer (1944) describes it to L. agilis exigua as broad and thin, covering large part of the lateral surface of the thoracic region, the fibers converge to a tendon inserting between the two long triceps heads. It usually takes its origin from the thoracodorsal fascia, as observed in. E. macularius, G. gecko, A. mississippiensis, $C$. siamensis, $C$. acutus, $O$. tetraspis and $G$. gangeticus, $C$. crocodilus crocodilus, C. latirostris, and Iguana i. iguana, extending to the ribs in $V$. exanthematicus. It inserts into the cranial surface of the humerus, except in $V$. exanthematicus, in which it occurs into a linear sulcus of the humeral shaft, between the proximal and middle thirds. In the crocodilians, the insertion tendon is common with $\mathrm{m}$. teres major, however, in C. latirostris, they are merely overlaid (JENKINS; GOSLOW, 1983; LIMA et al., 2016; MEERS, 2003; ROMÃO et al., 2013; ZAAF et al. 1999).

Tough it presents several nomenclatures, $\mathrm{mm}$. coracobrachialis brevis and coracobrachialis longus are anatomically conservative. We choose the nomenclature used by Jenkins and Goslow (1983) and Romer (1944) in V. exanthematicus and L. agilis exigua.

Muscle coracobrachialis brevis is a flexor of the shoulder joint, and it also performs retraction and adduction of the humerus. It is triangularshaped, occupying a broad area on the ventral surface of the coracoid, from where it arises. It inserts on the proximal humerus in E. macularius, G. gecko, C. crocodilus crocodilus and L. agilis exigua, occurring specifically on the deltopectoral crest in A. mississippiensis, C. siamensis, C. acutus, O. tetraspis, G. gangeticus, V. exanthematicus and Iguana i. iguana, and cranial to the deltopectoral crest in C. latirostris (JENKINS; GOSLOW, 1983; LIMA et al., 2016; MEERS, 2003; ROMÃO et al., 2013; ROMER, 1944; ZAAF et al. 1999).

Muscle coracobrachialis longus is fanshaped and it differs more than its short counterpart. Its primary function is to stabilize the head of the humerus in the glenoid, although it may assist in protraction and flexion of the forelimb (MEERS, 2003; ROMÃO et al., 2013). In crocodilians it originates from the scapula, on the dorsolateral surface in A. mississippiensis, C. siamensis, $C$. 
acutus, O. tetraspis and G. gangeticus, and from the medial proximal surface in $C$. latirostris, its insertion is close to the articular surface of humerus (MEERS, 2003; ROMÃO et al., 2013). L. agilis exigua, E. macularius, G. gecko, and I. iguana presents $\mathrm{m}$. coracobrachialis longus in a similar manner, originating from the dorsal surface of the coracoid and inserting onto the middle third of humerus. In $V$. exanthematicus on the other hand, it presents two indistinct heads and insertion on the epicondyle (JENKINS; GOSLOW, 1983; ROMER, 1944; ZAAF et al. 1999).

Presenting fan-shape and parallel fibers, $\mathrm{m}$. levator scapulae rotates the scapula cranially (MEERS, 2003; ROMÃO et al., 2013). Generally in tetrapods, it arises from the cervical ribs and inserts on the cranial margin of the scapula, as in the crocodilians (ABDALA; DIOGO, 2010; LIMA et al, 2016; MEERS, 2003; ROMÃO et al., 2013).

Some variations are reported for $\mathrm{m}$. levator scapulae, for instance to $C$. latirostris, in which we are only informed of the general origin location, the cervical level; we observed in Iguana i. iguana that the origin extends to the vertebral processes; $C$. crocodilus crocodilus, inserts on the craniodorsal margin; and in $C$. siamensis and $C$. acutus the insertion also attaches to the coracoid; in $V$. exanthematicus it presents two heads with common origin, the insertion of the ventral head is similar to the other reports, extending to the clavicle, and the dorsal head inserts on the lateral surface of the suprascapula (JENKINS; GOSLOW, 1983; LIMA et al., 2016; MEERS, 2003; ROMÃO et al., 2013).

The flexor action of the limb is performed by muscle biceps brachii, characteristically long, thin and superficial. According to Holmes (1977) and Dilkes (2000) m. biceps brachii usually takes its origin from the coracoid in reptiles, but it may present more than one belly in lepidosaurs. In agreement with these authors, $V$. exanthematicus, $L$. agilis exigua and Iguana i. iguana present two heads to $\mathrm{m}$. biceps brachii, however in $E$. macularius and G. gecko this separation is not described. (JENKINS; GOSLOW, 1983; ROMER, 1944; ZAAF et al. 1999).

In $L$. agilis exigua the two heads, proximal and distal, does not have a clear origin described, although its reported it exchange fibers with $\mathrm{m}$. braquial and inserts on the ulna and radius (ROMER, 1944). In V. exanthematicus, both heads takes its origin from the lateral surface of the coracoid. We observed in Iguana i. iguana, that only the distal head originates from the coracoid. The distal head of Iguana i. iguana, and both heads of $V$. exanthematicus, are overlaid by $\mathrm{m}$. pectoralis.
The belly is large and presents two insertions, one by the radius and the other by the ulna, in a tendon shaded with m. brachialis (JENKINS; GOSLOW, 1983).

The extension of the elbow is performed by muscle triceps brachii, and it shows variations of the nomenclature and origin. We found that the Iguana $i$. iguana $\mathrm{m}$. triceps is more similar to the crocodilians, described by Meers (2003), so we opted to use his nomenclature. E. macularius presents one scapular and two medial heads, the last ones from the medial side of the humeral shaft. In G. gecko it originates similarly to E. macularius, but with an additional head arising from the lateral shaft of the humerus (ZAAF et al. 1999). $V$. exanthematicus presents four heads, lateral, long (with two distinct origins) and medial. The lateral head (triceps brevis caudalis) takes its origin from the craniodorsal surface of the humeral shaft and an aponeurosis shared with $\mathrm{m}$. braquialis. The long head is divided into a caudal scapular part (triceps longus lateralis) it arises similar to that of $E$. macularius and G. gecko, from the posterolateral surface of the scapula. The cranial scapular (triceps longus caudalis) originates from a long and thin tendon along the caudal margin of the sternoescapular ligament and from a short tendon from m. latissimus dorsi. The medial head (triceps brevis intermedium) takes its origin from the dorsomedial surface of the humeral shaft. All the heads insert on the olecranon through the common triceps tendon (JENKINS; GOSLOW, 1983; ZAAF et al. 1999).

Historically, the group of extensor muscles of the limb is named triceps, perhaps from the terminology of domestic animals and humans. Analyzing reptile species, it becomes evident that a new classification is necessary, although it acts as the primary extensor of the arm; the morphology presents different aspects in each species described, though a common insertion is present, similar to mammals. It would be necessary an evolutionary investigation, taking into consideration ontogeny, innervation and possible functional alterations, about this group of muscular bellies, maybe concluding that not all of these muscles represent the triceps.

All crocodilians present an unusual origin to the long caudal head of $\mathrm{m}$. triceps brachii, via a tendinous arc, attaching the scapula and the coracoid (LIMA et al., 2013; MEERS, 2003; ROMÃO et al., 2016). This has only been described in crocodilians, and now we have observed this feature in Iguana $i$. iguana. However, it connects the scapula and the deltopectoral crest. Romão et al (2016) suggests that 
it may be related to the aquatic habits of these species. This finding may be of use in future investigations about the evolution of this feature, since more information is required.

The broad $\mathrm{m}$. extensor carpi ulnaris, according to Abdala and Diogo (2010), is fusiform and it is related to the extension of the limb, not the flexion, as proposed by Meers (2003). We observed in Iguana $i$. iguana the same origin as the crocodilians, in the cranial epicondyle of the humerus, similar to the lizards Tupinambis merianae, Polychrus acutirostris, Liolaemus sp. and Phymaturus sp., in the distal head of the humerus. It insets on the humeral shaft, the mentioned lizards has some fibers inserting on the aponeurosis of $\mathrm{m}$. flexor carpi ulnalis and pisiform bone (CASALS et al, 2012; LIMA et al., 2016; MEERS, 2003; MORO; ABDALA, 2004; 2006; ROMÃO et al., 2013).

Muscle extensor digitorum longus in crocodilians is nominated as $\mathrm{m}$. extensor carpi ulnaris longus (ABDALA; DIOGO, 2010; MEERS, 2003; ROMÃO et al., 2013). This difference in nomenclature is purely conceptual, because the function and topography are the same. It takes its origin from the distal head of the humerus ( $T$. merianae, Liolaemus sp., Phymaturus sp.; E. macularius and $G$. gecko), specifically on the cranial epicondyle of the humerus in $A$. mississippiensis, $C$. siamensis, $C$. acutus, $O$. tetraspis, G. gangeticus, $C$. latirostris, Iguana $i$. iguana. In $P$. acutirostris the origin is shared with $\mathrm{m}$. extensor carpi radialis, on the epicondyle (CASALS et al, 2012; LIMA et al., 2016; MEERS, 2003; MORO; ABDALA, 2004; 2006; ROMÃO et al., 2013).

The insertion of $\mathrm{m}$. extensor digitorum longus usually occurs on the metacarpals in reptiles, as observed in: crocodilians - base of metacarpal II; E. macularius, G. gecko, T. merianae, Liolaemus sp. and Phymaturus sp. - metacarpal bases II, III e IV; and $P$. acutirostris - metacarpals II, III e V. The insertion may occur in the phalanges, what is mostly observed in birds, however it was described inserting on the distal phalanges I e II, and we observed something similar in Iguana $i$. iguana, with it inserting also on the distal phalange III (ABDALA; DIOGO, 2010; CASALS et al, 2012; MEERS, 2003; MORO; ABDALA, 2004; 2006; ROMÃO et al., 2013; ZAAF et al. 1999). The proximal insertion on crocodilians and some lizards indicates a better positioning of the manus during the terrestrial locomotion. In Iguana $i$. iguana, the distal insertion improves the grip, making it easier movements in trees. Each variation, even small, can indicate a functional adaptation to its locomotion patterns.

In the lizards $T$. merianae, $P$. acutirostris, Liolaemus sp. and Phymaturus sp., the m. extensor carpi radialis originates from the distal humerus, by three heads - superficialis, intermedium e profundus - in the epicondyle. It inserts on the distal radius and radial carpal bone (CASALS et al, 2012; MORO; ABDALA, 2004; 2006), just as we observed in Iguana $i$. iguana, although we did not observe the division in three heads, corroborating Zaaf (1999) to E. macularius and G. gecko.

Muscle pronator teres is broad and thin, serving as the primary pronator of the zeugopodium, it may also flex the elbow joint, thus likely assisting in the maintenance of limb posture. It originates from the distal head of the humerus in $P$. acutirostris, Liolaemus sp., Phymaturus sp. and Varanus sp. In crocodilians, it takes its origin from the caudal epicondyle of the humerus, as we observed in Iguana i. iguana. It inserts on the distal third of the radius, except in $P$. acutirostris and Varanus sp., which occurs on the medial third and Liolaemus sp. and Phymaturus sp., which occurs on the proximal third (HAINES, 1950; LIMA et al, 2016; MEERS, 2003; MORO; ABDALA, 2004; 2006; ROMÃO et al, 2013).

The main flexor of the digits is the fusiform m. flexor digitorum longus, it usually presents two heads to lizards. E. macularius and G. gecko, $P$. acutirostris, Liolaemus sp. and Phymaturus sp. present radial and ulnar heads, originating through a tendon on the distal head of the humerus and ulna, consistent with what we observed in Iguana $i$. iguana (MORO; ABDALA, 2004; 2006). In Varanus sp. it presents five heads, three from the humerus, a deep from the ulna shaft and a carpal head from ulnar carpal bone (HAINES, 1950, MORO; ABDALA, 2004; 2006; ZAAF et al. 1999).

Not necessarily, species with numerous bellies present a better function in a specific muscle. The fact that we did not observe a clear division in the $\mathrm{m}$. flexor digitorum longus in Iguana i. iguana, may represent a derived condition of this muscle, allowing more strength during contraction. In transversal section, the muscle with larger section area possesses greater efficiency, facilitating activities such as grabbing, which demands more strength of the flexor musculature.

The ontogeny of the distal elements tends to vary deeply, reflecting the functional differences during evolution. Loss and fusion represent the main changes on the framework of the vertebrates. Small size is another important feature, because in muscles 
it is directly connected to the ability to execute elaborated movements in digits.

We observed with ease the presence of several muscles, including the ones that are conservative, without many variations of the morphological features in reptiles and other tetrapods. The proximal segments are more diverse than the distal ones, perhaps due to the smaller size or it may reflect the specialization of the different patterns of locomotion among the species. The similar features are probably due to the related habits and behaviour.

The specific reptile literature shows a relative conservatism among this group, concerning its framework. Although we only used two specimens, we considered that the muscular anatomy also follows this pattern. Even though some variations may occur, the general template can be considered the same to all Iguana i. iguana.

\section{ACKNOWLEDGMENTS}

We thank Marina Sartori, Lucélia Vieira and André Quagliatto for their support and donation of the specimens.

RESUMO: Iguanas verdes tem hábitos arbóreos, terrestres e aquáticos, e são totalmente herbívoras. Tem ampla distribuição na América Central e do Sul, habitando vários biomas no Brasil. Investigações diversas tiveram esta espécie como foco, embora informações morfológicas sejam ainda escassas. Objetivando adicionar dados ao conhecimento anatômico, dois espécimes de Iguana i. iguana foram obtidos post mortem, por doação de um criadouro científico, e dissecados. Os músculos foram individualizados para identificação e descrição das origens, inserções e características. Alguns músculos, como o coracobraquial curto, apresentam morfologia conservativa, sua origem ocorre na superfície ventral do coracóide e inserção na epífise proximal do úmero. O trapézio, o bíceps braquial e o deltóide clavicular se apresentam similares à outros répteis, com a origem do trapézio na fáscia toracodorsal e o bíceps, com duas cabeças, se inserindo no tubérculo do rádio. O deltóide clavicular possui o tendão de inserção unido ao do músculo deltóide escapular. O músculo peitoral apresenta variações em sua origem e divisões, mas a inserção sempre ocorre na crista deltopeitoral. A origem da cabeça longa caudal do tríceps ocorre por meio de arco tendíneo, característica antes descrita apenas em crocodilianos. A musculatura de Iguana i. iguana se apresenta similar à de outros répteis no geral, com características próprias refletindo seus hábitos.

PALAVRAS-CHAVE: Musculatura. Cintura peitoral. Iguana verde. Répteis.

\section{REFERENCES}

ABDALA, V.; DIOGO, R. Comparative anatomy, homologies and evolution of the pectoral and forelimb musculature of tetrapods with special attention to extant limbed amphibians and reptiles. Journal of Anatomy, v. 217, p. 536-573, 2010. https://doi.org/10.1111/j.1469-7580.2010.01278.x

AKITA, K. An anatomical investigation of the muscles of the pelvic outlet in Iguanas (Iguanidae Iguana iguana) and Varanus (Varanidae Varanus (dumerillii)) with special reference to their nerve supply. Annals of Anatomy, v. 174, n. 2, p. 119-129, 1992. https://doi.org/10.1016/S0940-9602(11)80328-6

AVERY, R. A.; MUELLER, C. F.; SMITH, J. A.; BOND, D. J. The movement patterns of lacertid lizards: speed, gait and pauses in Lacerta vivipara. Journal of Zoology, v. 211, n. 1, p. 47-63, 1987.

https://doi.org/10.1111/j.1469-7998.1987.tb07452.x

BARTEN, S. L. Green Iguana Management and Husbandry. Iguana, v. 10, n. 4, p. 129-141, 2003.

BLAIR, D. Green Iguanas: Emerald Gems of the Jungle. Iguana Times, v. 4, n. 3, p. 41-47, 1995.

BRINKMAN, D. The hind limb step cycle of Iguana and primitive reptiles. Journal of Zoology, v. 193, n. 1, p. 91-103, 1981. https://doi.org/10.1111/j.1469-7998.1981.tb01493.x 
CAMPOS, Z.; DESBIEZ, A. Structure of Size and Reproduction of Green Iguanas (Iguana iguana) in the Brazilian Pantanal. IRCF Reptiles \& Amphibians, v. 20, n. 2, p. 53-56, 2013.

CARRIER, D. Activity of the hypaxial muscles during walking in the lizard Iguana iguana. Journal of Experimental Biology, v. 152, n. 1, p. 453-470, 1990.

CASALS, J. B.; GODOY, N. C. P.; CURY, F. S.; PASKOSKI, L. B.; OLIVEIRA, M. F.; MARTINS, D. S.; PESSÔA, L. V. F.; MIGLINO, M. A.; AMBRÓSIO, C. E. Descrição macroscópica da musculatura dos membros do Tupinambis merianae. Biotemas, v. 25, n. 1, p. 103-109, 2012.

COSTA, H. C.; BÉRNILS, R. S. Répteis brasileiros: Lista de espécies 2015. Herpetologia Brasileira, v. 4, n. 3, p. 75-93, 2015.

DILKES, D. W. Appendicular myology of the hadrosaurian dinosaur Maiasaura peeblesorumfrom the Late Cretaceous (Campanian) of Montana. Transactions of the Royal Society of Edinburgh Earth Sciences, v. 90, p. 87-125, 2000. https://doi.org/10.1017/S0263593300007185

FARLEY, C. T.; KO, T. C. Mechanics of locomotion in lizards. Journal of Experimental Biology, v. 200, n. 16, p. 2177-2188, 1997.

HAINES, R. W. A revision of the extensor muscles of the forearm in tetrapods. Journal of Anatomy, v. 73, p. 211-33, 1939.

HAINES, R. W. The flexor muscle of the forearm and hand in lizards and mammals. Journal of Anatomy, v. 84, p. 13-29, 1950.

HOLMES, R. The osteology and musculature of the pectoral limb of small captorhinids. Journal of Morphology, v. 152, p. 101-140, 1977. https://doi.org/10.1002/jmor.1051520107

JENKINS, F. A.; GOSLOW, G. E. The Functional Anatomy of the Shoulder of the Savannah Monitor Lizard (Varanus exanthematicus). Journal of Morphology, v. 175, p. 195-216, 1983.

https://doi.org/10.1002/jmor.1051750207

KARDONG, K. V. Sistema Muscular. In: 5. São Paulo: Roca, 2014. Cap. 10, p. 439-485.

LIEM, K. F.; BEMIS, W. E.; WALKER JR., W. F.; GRANDE, L. Anatomia funcional dos vertebrados: Uma perspectiva evolutiva. Ed. 3. São Paulo: Cengage Learning, 2012.

LIMA, F. C.; LEITE, A. V.; SANTOS, A. L. Q.; SABEC-PEREIRA, D. K.; ARAÚJO, E. G.; PEREIRA, K. F. Muscular anatomy of the pectoral and forelimb of Caiman crocodilus crocodilus (Linnaeus, 1758) (Crocodylia: Alligatoridae), Ciência Animal Brasiliera, v. 12, n. 2, p. 285-295, 2016. https://doi.org/10.1590/10896891 v17i233788

MEERS, M. B. Crocodylian Forelimb Musculature and Its Relevance to Archosauria. The Anatomical Record, v. 274, p. 891-916, 2003. https://doi.org/10.1002/ar.a.10097

MORO, S.; ABDALA, V. Análisis descriptive de la miología flexora y extensora del miembro anterior de Polychrus acutirostris (Squamata, Polychrotidae). Papéis Avulsos de Zoologia, v. 44, n. 5, p. 81-89, 2004. https://doi.org/10.1590/S0031-10492004000500001

MORO, S.; ABDALA, V. Comparative myology of the forelimb of Liolaemus sand lizards (Liolaemidae). Acta Zoologica, v. 87, p. 1-12, 2006. https://doi.org/10.1111/j.1463-6395.2006.00215.x 
PETERSON, J. A. The locomotion of Chamaeleo (Reptilia: Sauria) with particular reference to the forelimb. Journal of Zoology, v. 202, n. 1, p. 1-42, 1984. https://doi.org/10.1111/j.1469-7998.1984.tb04286.x

ROMÃO, M. F.; SANTOS, A. L. Q.; LIMA, F. C. Anatomia descritiva aplicada à cinesiologia e biomecânica básica dos músculos da cintura peitoral, estilopódio e zeugopódio do jacaré do papo amarelo. Ciência Rural, v. 43, n. 4, p. 631-638, 2013. https://doi.org/10.1590/S0103-84782013005000027

ROMER, A. S. The development of the tetrapod limb musculature - the shoulder region of Lacerta. Journal of Morphology, v. 74, n. 1, p. 1-41, 1944. https://doi.org/10.1002/jmor.1050740102

RITTER, R. Lateral bending during lizard locomotion. Journal of Experimental Biology, v. 173, n. 1, p. 1-10, 1992.

RUSSELL, A. P.; BAUER, A. M. The appendicular locomotor apparatus of Sphenodon and normal-limbed squamates. In: GANS, C. DAWSON, W. R. Biology of the Reptilia, v. 21, Physiology, Academic Press, London, New York, San Francisco p. 1-465, 2008.

SWANSON, P. L. The Iguana Iguana iguana iguana (L). Iguana, v. 11, n. 3, p. 179-182, 2004.

WALKER, W. F. The locomotor apparatus of testudines. Biology of the Reptilia, v. 14, p. 1-100, 1973.

ZAAF, A.; HERREL, A.; AERTS, P.; VREE F. Morphology and morphometrics of the appendicular musculature in geckoes with different locomotor habits (Lepidosauria). Zoomorphology, v. 119, n. 1, p. 9-22, 1999. https://doi.org/10.1007/s004350050077 